\title{
Equity in the Nursing Agenda
}

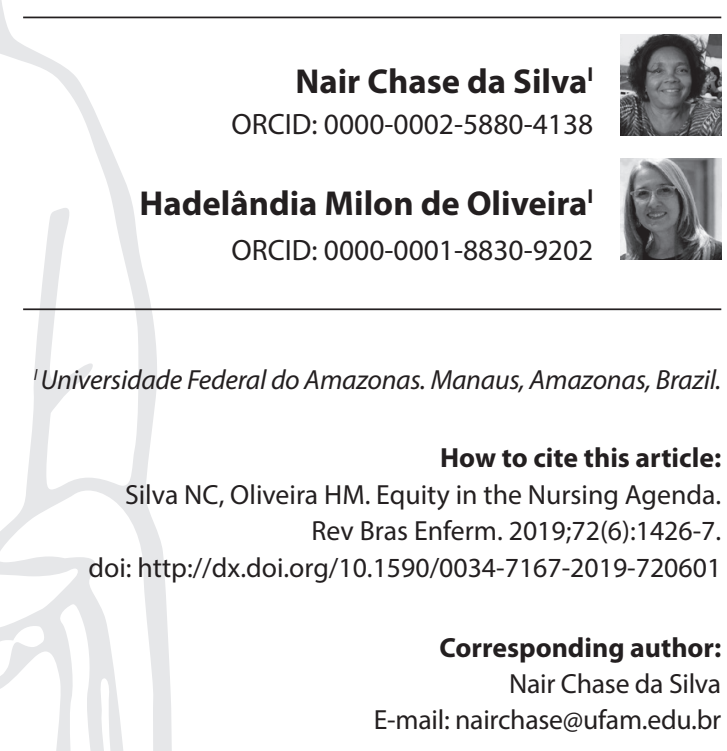

Meaningful themes have been the subject of nursing reflection in their events. The careful and qualified look of nursing over the individual, family, and community has always been and always will be its essence. This includes considering the biological, economic, social, and environmental determinants.

Defender and faithful to the philosophical principles of SUS (Sistema Único de Saúde - Brazilian Unified Health System) - the master spring of the Brazilian health system - nursing has brought to the discussion of its events the foundations of this system, from its conception, following the adjustments made over the years, such as social policies that seek to achieve success by understanding the dynamism of society. The conviction that SUS has the potential to improve the quality of life and health of the Brazilian people is the key to understanding the reason of this compliance.

In this $71^{\text {st }}$ Brazilian Congress of Nursing, the category retakes the Principle of Equity, a topic already discussed in previous Congresses. Likewise, SUS, at the $16^{\text {th }}$ National Health Conference - CNS (Conselho Nacional de Saúde - National Health Board) $\left(8^{\text {th }}+8\right)$, in discussing "Democracy and Health" in 2019 , resumes its basic principles.

Although Equity is a little diffused principle in relation to the others, there are advances, mainly in the horizontal equity - equal treatment for peers, through the implementation of the Family Health Strategy ${ }^{(1)}$ and the implementation of other empowering devices, such as the Pacto em Defesa do SUS (Pact in Defense of SUS) and the New PNAB (Política Nacional de Atenção Básica - National Primary Care Policy). This policy was the one that legalized a legitimate strategy of the Amazonian peoples, that is, the "ambulanchas" (watercraft with characteristics of an ambulance). Nursing, committed to society and to the profession, keeps up with this movement, recognizing that it is necessary to strengthen the struggle for human rights, hitherto built with great effort. It is vital to resist dismounting. The implementation of social policies does not consolidate overnight. It is necessary to invest daily in order to reduce inequalities, to give voice to the social movements hitherto excluded and to strengthen those who through the militancy have managed to advance more structured. This is the way to strengthen the Brazilian Rule of Law and democracy.

The strengthening of equity in SUS, replacing the merely formal facet of the principle of equality, has been gaining corporeity since the institution of human rights policy, as a result of the claim of marginalized social movements. The sense of belonging to the group, and the elevation of their self-esteem pressured the state to recognize their differences, to open space in all segments of society, to denounce the prejudice that generates inequality and classifies the citizens as first, second and third class. The black, indigenous and LGBTI were pioneers in this process, opening space for other minority and marginalized groups.

When using the concept of equality as justice, there must go beyond justice. Because it is universal, given its linear character, it does not consider the particularities, individual, and collective differences, which are those who actually promote equity through social justice, giving more to those who need more, and less to those who need less ${ }^{(2)}$. Equity is a sensitive indicator of health policies, because it goes beyond what is established in the law, that all are equal before SUS. By taking this guideline, it meets, as 
far as necessary the groups, without giving more to those who need less and less to those who need more. From this perspective, equity goes beyond the courts, as Kant rightly asserted, "it is a matter of conscience".

Given the degree of complexity, it is necessary for health professionals to be prepared for this new look, in order to give up anachronistic values, some rooted from childhood. In this sense, understanding and applying Equity is fundamental to improving the exercise of duties, as well as enforcing rights and guarantees, so that there can be achieved, as prescribed in the Brazilian Constitution, a free, fair and solidary society, which is one of its fundamental objectives.

\section{REFERENCES}

1. Siqueira SAV, Hollanda E, Motta JIJ. Políticas de Promoção de Equidade em Saúde para grupos vulneráveis: o papel do Ministério da Saúde. Ciênc Saúde Coletiva, Rio de Janeiro, 2017;22(5):1397. doi: 10.1590/1413-81232017225.33552016

2. Jardanovski E, Guimarães PCV. O Desafio da equidade no setor saúde. Rev Adm Empres. São Paulo; 1993;33(3):38-51. doi: 10.1590/ S0034-75901993000300004 